


\section{The roots of populism}

\section{MANCHESTER 1824}

Manchester University Press 
Brian Elliott - 9781526136985 Downloaded from manchesterhive.com at $04 / 26 / 2023$ 09:28:47AM via free access 


\title{
The roots of populism
}

Neoliberalism and working-class lives

\author{
Brian Elliott
}


The right of Brian Elliott to be identified as the author of this work has been asserted by them in accordance with the Copyright, Designs and Patents Act 1988.

Published by Manchester University Press

Altrincham Street, Manchester M1 7JA

www.manchesteruniversitypress.co.uk

British Library Cataloguing-in-Publication Data A catalogue record for this book is available from the British Library

ISBN 9781526136978 hardback

First published 2021

The publisher has no responsibility for the persistence or accuracy of URLs for any external or third-party internet websites referred to in this book, and does not guarantee that any content on such websites is, or will remain, accurate or appropriate.

Cover image: Unknown author, The Houses of Parliament (1903), Leonard A. Lauder collection of Raphael Tuck \& Sons postcards, The Newberry

Cover design: Abbey Akanbi, Manchester University Press

Typeset by

Servis Filmsetting Ltd, Stockport, Cheshire 